\title{
Prevalence and incidence estimates for syphilis, chlamydia, gonorrhea, and congenital syphilis in Colombia, 1995-2016
}

\author{
Eline L. Korenromp, ${ }^{1}$ Cielo Ríos, ${ }^{2}$ Amparo Liliana Sabogal Apolinar, ${ }^{3}$ Sidia Caicedo, ${ }^{2}$ Diego Cuellar, ${ }^{2}$ \\ Iván Cárdenas, ${ }^{2}$ Ricardo Luque Nuñez, ${ }^{2}$ Norma Constanza Cuéllar, ${ }^{3}$ Martha Ruíz, ${ }^{2}$ Adriana Cruz, ${ }^{4}$ \\ Hernando Gaitan-Duarte, ${ }^{5}$ Carolina Duarte Valderrama, ${ }^{3}$ María Isabel Bermúdez Forero, ${ }^{3}$ \\ Melanie Taylor, ${ }^{6}$ Jane Rowley, ${ }^{7}$ Bertha Gómez, ${ }^{8}$ and Mónica Alonso ${ }^{9}$
}

Suggested citation Korenromp EL, Rios C, Sabogal A, Caicedo S, Cuellar D, Cardenas I, et al. Prevalence and incidence estimates for syphilis, chlamydia, gonorrhea, and congenital syphilis in Colombia, 1995-2016. Rev Panam Salud Publica. 2018;42:e118. https:// doi.org/10.26633/RPSP.2018.118

ABSTRACT Objectives. To estimate adult (15-49 years old) prevalence and incidence of active syphilis, gonorrhea, and chlamydia, and incidence of congenital syphilis (CS) and adverse birth outcomes (ABOs) in Colombia, over 1995-2016.

Methods. The Spectrum-STI epidemiological model tool estimated gonorrhea and chlamydia prevalences as moving averages across prevalences observed in representative general population surveys. For adult syphilis, Spectrum-STI applied segmented polynomial regression through prevalence data from antenatal care (ANC) surveys, routine ANC-based screening, and general population surveys. CS cases and ABOs were estimated from Spectrum's maternal syphilis estimates and proportions of women screened and treated for syphilis, applying World Health Organization case definitions and risk probabilities.

Results. The Spectrum model estimated prevalences in 2016 of $0.70 \%$ (95\% confidence interval (CI): $0.15 \%-1.9 \%)$ in women and $0.60 \%(0.1 \%-1.9 \%)$ in men for gonorrhea and of $9.2 \%(4.4 \%-$ $15.4 \%)$ in women and $7.4 \%$ (3.5\%-14.7\%) in men for chlamydia, without evidence for trends over 1995-2016. The prevalence of active syphilis in 2016 was 1.25\% (1.22-1.29\%) in women and $1.25 \%(1.1 \%-1.4 \%)$ in men, decreasing from $2.6 \%(2.1 \%-3.2 \%)$ in women in 1995 . Corresponding CS cases in 2016 (including cases without clinical symptoms) totaled 3 851, of which 2245 were ABOs. Annual CS and ABO estimates decreased over 2008-2016, reflecting decreasing maternal prevalence and increasing cases averted through ANC-based screening and treatment.

Conclusions. The available surveillance and monitoring data synthesized in SpectrumSTI-and the resulting first-ever national STI estimates for Colombia-highlighted Colombia's persistently high STI burden. Adult syphilis and congenital syphilis are estimated to be falling, reflecting improving screening efforts. Strengthened surveillance, including with periodic screening in low-risk populations and future refined Spectrum estimations, should support planning and implementation of STI prevention and control, including CS elimination.

Keywords Sexually transmitted infection; syphilis; gonorrhea; chlamydia; surveillance; Colombia.

Avenir Health, Geneva, Geneva, Switzerland.

Ministry of Health and Social Protection, Bogotá, Bogotá, Colombia.

National Health Institute, Bogotá, Bogotá, Colombia.
International Training Center and Medical Research, Cali, Colombia.

National University of Colombia, Bogotá, Colombia.

World Health Organization, Department of

Reproductive Health and Research, Geneva, Switzerland.
Independent consultant, London, London, United Kingdom.

Pan American Health Organization, Bogotá, Bogotá, Colombia.

Pan American Health Organization, Washington D.C., United States of America. 
In 1993, Colombia phased out sexually transmitted infection (STI) programs, as part of broader changes to the national health system, including the adoption of a social security system. Currently, Colombia is addressing STIs through its national STI/HIV plan for 2014-2017 (1), including with building awareness of STIs and HIV; promoting condom use; conducting screening for syphilis and HIV; and utilizing a syndromic approach for other STIs (1). Coverage for antenatal care (ANC) is over $95 \%$. The screening and the treating of pregnant women for syphilis are free of charge and are reported to be at $62 \%$ and $94 \%$, respectively (2). Through the national surveillance system, there are case reports of congenital syphilis and of gestational syphilis. However, there is no surveillance of cases of resistant strains of Neisseria gonorrhoeae or Chlamydia trachomatis, nor are there adult syphilis registers.

This article describes the application of the Spectrum-STI epidemiological model (http://avenirhealth.org/software-spectrum.php) to develop prevalence and incidence estimates for syphilis, gonorrhea, and chlamydia among the population 15-49 years old in Colombia over 19952016. This was the first-ever calculation of the national adult STI burden in Colombia, and the first application of the Spectrum-STI model in a country in the Americas. The article also describes using the estimated prevalence of syphilis in adult women to estimate congenital syphilis (CS) incidence and associated adverse birth outcomes (ABOs) (3-7). These estimates aim to assist in strengthening Colombia's national STI surveillance and control efforts.

\section{METHODS}

The Spectrum-STI estimation tool was used to estimate the prevalence of active syphilis, gonorrhea, and chlamydia in adults 15-49 years old.

\section{Adult gonorrhea and chlamydia estimation}

Spectrum-STI fits a moving average time trend of gonorrhea and chlamydia prevalence for adult women, through available data points. Prevalence data were identified from studies conducted between 1995 and 2016 in populations representative of Colombia's general adult population, identified through a PubMed search and by national STI experts during a national STI estimation workshop in May 2017 (8). Qualifying surveys include those among pregnant women, women attending family planning clinics, and adult women or men tested through household surveys. The limited national prevalence data were supplemented by prevalence surveys from two neighboring countries, Brazil and Peru.

Prevalence data from each study were adjusted for diagnostic test performance ((9-11); Annex 1), using fixed sensitivities and specificities (4). Using the approach of the 2012 regional STI estimation methodology of the World Health Organization (WHO) (9), studies conducted in exclusively rural or urban sites were converted into a national prevalence by applying a rural-to-urban ratio of 0.9 , and Colombia's annual urban and rural population sizes (12). Each prevalence data point was adjusted upward by $10 \%$ to account for the contribution of higher-risk populations typically undersampled in general population surveys (9).

Male data points were merged into the female data set, assuming a maleto-female prevalence ratio of 0.86 (range of $0.58-1.15$ ) for gonorrhea and 0.80 (0.53-1.07) for chlamydia, as in WHO's 2012 estimates (9), with uncertainty bounds combining uncertainty in female prevalences and in male-tofemale prevalence ratios.

Spectrum-STI users assign weights to each data point contributing to the estimation, according to their representativeness. For Colombia's gonorrhea and chlamydia estimations, national surveys were each weighed at $100 \%$, and neighboring country surveys at $10 \%$.

National prevalence estimates for adult males were inferred from female estimates, using the same male-to-female ratios as were used to translate male data into female data.

\section{Adult syphilis estimation}

Spectrum-STI fits a time trend through prevalence data, applying segmented polynomial regression $(13,14)$ using second-order splines constrained in a $0 \%-20 \%$ prevalence range, with knots positioned at five-year intervals
(7). Eligible data were from surveys of women in ANC, routine ANC-based syphilis screening, and representative general population surveys. All datafrom ANC women, non-ANC women, and men-were pooled assuming no systematic prevalence differences between them, as in the 2012 WHO methodology (9) and supported by a global meta-analysis of risk factors for adult syphilis (15).

Data were adjusted for diagnostic test performance to ensure they reflected active syphilis (defined as concurrent positivity on both nontreponemal rapid plasma reagin (RPR) tests and Treponema pallidum tests). Additionally, prevalence data were adjusted upward by $10 \%$ to account for undersampling of high-risk populations in surveys (9). Each data point was assigned a weight according to its national coverage and representativeness (Annex 2 and Annex 3).

\section{Adult STI incidence estimation}

Incidence was derived from prevalence by applying average durations of infection to estimated prevalence $(4,5)$, weighted between episodes treated and of shorter duration, and episodes untreated of a longer duration. Per consensus among experts at the 2017 national workshop (8), STI episode durations were those used in the 2012 WHO methodology for countries with low treatment access (9). These assumed that an average of $35 \%$ of men with symptomatic gonorrhea, chlamydia, or syphilis are treated. In comparison, in Colombia's 2015 national Demographic and Health Survey (16), of men who reported having had an STI in the past year, 51\% reported having received treatment, but we kept to the $35 \%$ value so as to not overestimate numbers of incident cases for a given prevalence, and not underestimate reporting completeness.

Assuming 35\% treatment coverage of symptomatic gonorrhea and chlamydia episodes in men, and $22.5 \%$ for symptomatic women (9), average durations of gonorrhea and chlamydia episodes, weighted between fractions treated and untreated, were 0.32 years for gonorrhea and 0.86 years for chlamydia in men, and 0.47 years for gonorrhea and 1.22 years for chlamydia in women. For syphilis, the average assumed duration was 2.9 years in both men and women, 
similar to assumptions for other countries with low to moderate treatment access prior to $2012(5,9)$.

\section{Estimation of congenital syphilis and adverse birth outcomes}

$\mathrm{CS}$ and $\mathrm{ABO}$ cases were projected using Spectrum's estimated syphilis prevalence in ANC women (assumed to be the national Spectrum estimate for women, but without the $+10 \%$ adjustment for missing high-risk populations), proportions of women screened and treated, annual numbers of pregnancies, and a tool developed by WHO to estimate CSattributable $\mathrm{ABO}$ at country and global levels $(17,18)$.

Service coverage data (proportions of pregnant women who attended ANC at least once (ANC-1); women attending ANC screened for syphilis; and women screened, identified as positive, and treated appropriately) was used to estimate the fraction and number of pregnant women whose syphilis remained untreated. The coverage of ANC-1 and of syphilis screening were assumed equal in women with and without active syphilis. ANC-1 coverage was based on data from national demographic and health surveys $(16,19)$ (Annex 3 ). Missing values were interpolated from values at years with data before and after. Numbers and proportions of pregnant women in ANC screened and treated for syphilis were available from routine records.

For overall CS cases, the estimation used the WHO's case definition of CS, recommended for surveillance purposes (20):

- a stillbirth, live birth, or fetal loss at $>20$ weeks of gestation or > 500 grams to a syphilis-seropositive mother without adequate syphilis treatment; OR

- a stillbirth, live birth, or child aged $<2$ years with microbiological evidence of syphilis infection.

According to this definition, the estimation included all infants (with or without clinical findings at birth) born to women with untreated syphilis, as well as live-born infants with clinical findings of CS born to women with treated infections. Infants born with clinical findings of $\mathrm{CS}$ are a subset of the $\mathrm{ABO}$ s defined above, which also include stillbirths, neonatal deaths, and premature or low birthweight babies born to mothers with untreated syphilis. Thus, all pregnancies with untreated maternal syphilis were counted as CS (including the estimated $52 \%$ with an $\mathrm{ABO}(21)$ and the remaining $48 \%$ of births to undiagnosed and inadequately treated women without clinical signs or symptoms). In addition, we counted ABOs that occurred to women with treated syphilis as CS cases.

In Colombia, due to ANC-1 and syphilis screening coverages being below $100 \%$, some pregnant women with syphilis had not been diagnosed, and these women could in practice not be counted among reported CS cases, although they fall under WHO's CS surveillance case definition. To provide total CS case burden (including CS case numbers expected to be reported if surveillance were $100 \%$ complete), we estimated total CS cases, as well as the subset of CS cases expected to be reported from among women with syphilis serology known through ANC-based screening.

The ABO calculation applied risk probabilities estimated through a metaanalysis of various types of adverse birth outcomes (21). For women with untreated syphilis, the risk probabilities were: stillbirth, 21\%; neonatal death, $9 \%$; prematurity/low birthweight, $6 \%$; and clinical CS, 16\%. Those values add to a total of $52 \%$ with any ABO (21). For women whose syphilis was treated during pregnancy, these risks were reduced by the estimated effectiveness of treatment: $82 \%$ reduction for stillbirth (22), $80 \%$ reduction for neonatal death (22), $64 \%$ reduction for prematurity/low birthweight (21), and $97 \%$ reduction for clinical CS (21). This leaves an overall remaining risk of $8 \%$ of any CS-attributable $\mathrm{ABO}$ among treated mothers (22), related to treatment (too) late in pregnancy, inadequate treatments, and/or reinfection after syphilis treatment.

\section{Completeness of congenital syphilis case reporting}

Completeness of CS case reporting was evaluated by comparing CS case numbers reported by the national surveillance system (Annex 4) with CS cases estimated by Spectrum, according to the WHO case definition (20).

\section{Sensitivity analysis}

Univariate sensitivity analyses assessed sensitivity of 2016 estimates to key assumptions. Parameters varied focused on Colombia-specific input data and assumptions, notably the available prevalence data and their relative weights. More general and global assumptions of the Spectrum methodology have been addressed elsewhere $(3,7)$.

\section{RESULTS}

\section{Gonorrhea prevalence}

For gonorrhea, four qualifying population-based prevalence surveys were identified from within Colombia, each in one or two selected cities or towns, over 1995-2013 (Annex 1; Figure 1a). To supplement these Colombia data, data from Brazil (five surveys, 2002-2009) and Peru (two surveys, 1998 and 2001) were also included (at 10\% weight).

Spectrum estimated gonorrhea prevalence at $0.70 \%$ (95\% confidence interval (CI): $0.15 \%-1.9 \%$ ) in women (Figure 1a) and $0.60 \%(0.12 \%-1.9 \%)$ in men in 2016 (Table 1). Estimated prevalence was lower in $1995(0.20 \%)$, the year with the first available survey within Colombia, and it peaked in 2004 (1.0\%). The wide confidence intervals on the estimates, which were based on selected studies in different sites and populations, precluded a formal, statistical assessment of historic trends; our descriptions of time trends reflect visual examination.

\section{Chlamydia prevalence}

For chlamydia, qualifying data from within Colombia were 5 surveys from selected cities or towns, spanning 1995 to 2013, supplemented with 11 surveys from Brazil (2000-2012) and 3 surveys from Peru (1998 to 2013). Chlamydia prevalence was estimated at $9.2 \%(4.4 \%$ $15.4 \%$ ) in women (Figure $1 \mathrm{~b}$ ), and $7.4 \%$ $(3.5 \%-14.7 \%)$ in men in 2016 (Table 1). These rates were slightly higher than for 1995 , when women's prevalence was estimated at $5.3 \%(3.6 \%-7.6 \%)$.

\section{Syphilis prevalence}

For syphilis, estimates were based on four ANC sentinel surveys (1997 and 
FIGURE 1. Trends in the prevalence of gonorrhea, chlamydia, and active syphilis in women 15-49 years old in Colombia, 1990-2016

\section{(a) Gonorrhea}

Surveys, Bogotá, Risaralda, Montería, women

$\triangle$ Surveys, Peru, women

- Surveys, Brazil, women

$\diamond$ Andean Americas estimate, WHO

* Surveys Colombia, nonrepresentative

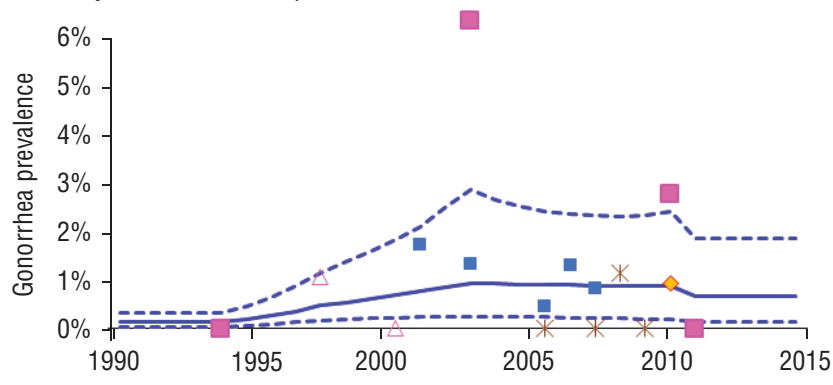

(b) Chlamydia

- Surveys, Bogota, Risaralda, Montería, women

$\triangle$ Surveys, Peru, women

- Surveys, Brazil, women

$\diamond$ Andean Americas estimate, WHO

* Surveys Colombia, nonrepresentative

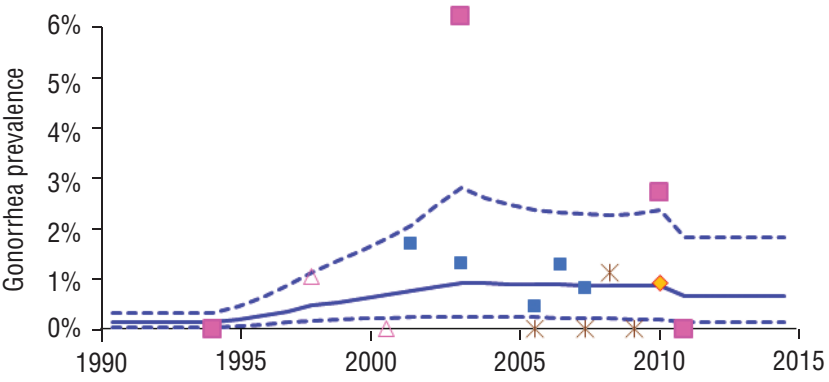

(c) Active syphilis

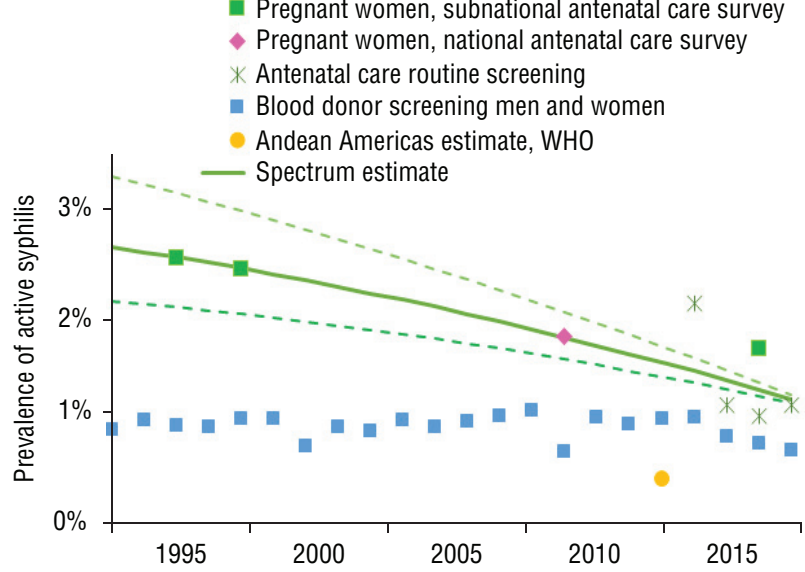

Source: Prepared by the authors from the study's estimations and the underlying data presented in the supplementary annexes.

a The prevalence data are shown after adjustments for diagnostic test performance, geography, and high-risk populations (Annex 1 and Annex 2), as described in the Methods section of this article. The solid lines are best estimates; the dotted lines are $95 \%$ confidence intervals. The World Health Organization (WHO) 2012 estimates for the Central America region (for gonorrhea and chlamydia) and the Andean region (for syphilis) (both from Newman et al. (9)) are shown for reference, but were not used in the estimations for Colombia. For gonorrhea and chlamydia, the "surveys Colombia, nonrepresentative" data were not used in the best estimates but were included in the sensitivity analysis (which is presented in Table 2 of this article). For syphilis, "blood donor screening, men and women" data were not used in the best estimates but were included in the sensitivity analysis (Table 2).

TABLE 1. Spectrum-estimated sexually transmitted infection (STI) prevalence, incidence rate (per 100000 person-years), and incident case numbers, with the $95 \%$ confidence interval $(\mathrm{Cl})$, in women and men 15-49 years old, Colombia, 2016

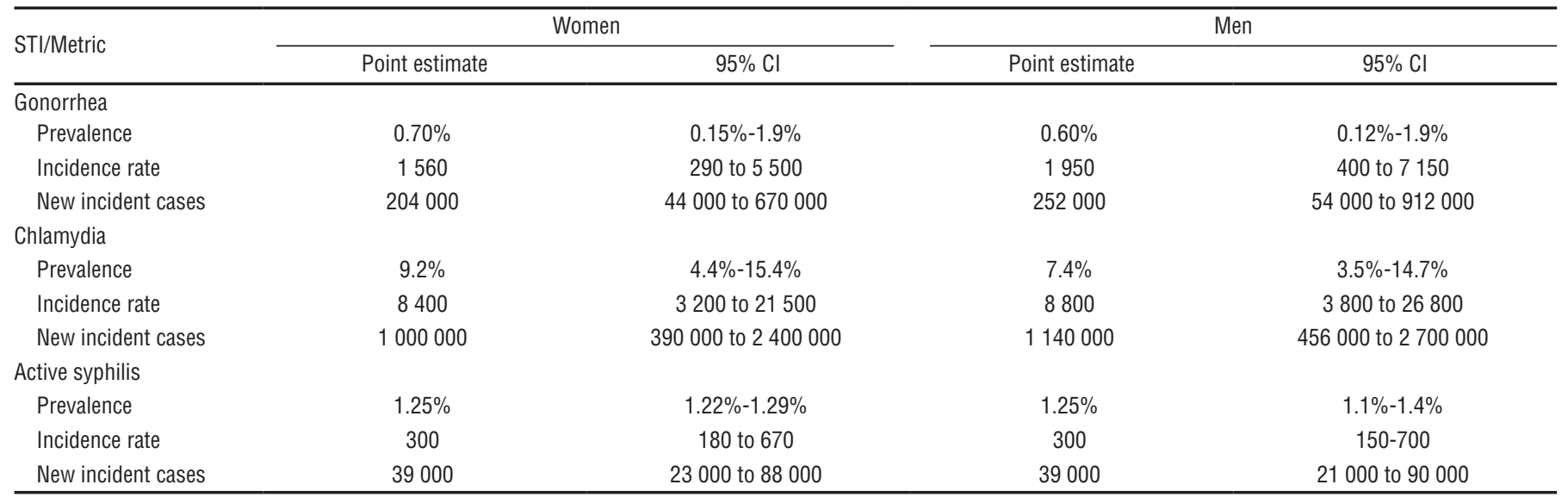

Source: Prepared by the authors from the study's estimations and the underlying data presented in the annexes. 
1999 in Bogotá, a national sentinel survey in 2009, and Bogotá and Cali in 2015) (Annex 2) and nationwide routine ANC-based screening over 2013-2016 (Annex 3). Between 2009 and 2012, numbers of syphilis diagnoses among ANC women through routine screening were also available, but the numbers of women screened were not recorded, so these data could not be used.

The estimated prevalence was $1.25 \%$ $(1.22 \%-1.29 \%)$ in women and $1.25 \%$ $(1.1 \%-1.4 \%)$ in men in 2016 , with a gradual decline from an estimated $2.6 \%$ in women and men in 1995 (Figure 1c).

\section{Adult case incidence}

With adult case incidence in 2016, Spectrum estimated 204000 (44000 to 670000 ) and 252000 (54000 to 834000 ) new gonorrhea cases (i.e., episodes), respectively, in women and men aged 15-49 years, and 1000000 (390 000 to 2400 000) new cases of chlamydia in women and $1 \quad 140 \quad 000 \quad(456 \quad 000$ to 2700 000) in men (Table 1). For both STIs, case incidence rates and numbers (Table 1) were higher in men than women, despite higher prevalence in women, reflecting longer duration of infection in women.

For syphilis, Spectrum estimated 39000 (23 000 to 88000$)$ new cases in women and 39000 (21 000 to 90000$)$ new cases in men in 2016, reflecting the assumed equal male and female syphilis rates.
Time trends in case incidence (not shown) mirrored time trends in prevalence (Figure 1), since treatment coverage and durations of infection were assumed constant over 1995-2016 for all three STIs.

\section{Congenital syphilis and adverse birth outcomes}

CS and ABOs were estimated for 20082016, the years with data available for ANC-based screening and treatment coverage. For 2016, of 3851 estimated CS cases, 2245 were ABOs (Figure 2a), numbers which had gradually declined since 2008, reflecting declining maternal prevalence (Figure 1c) and increasing coverages of ANC-based syphilis screening and treatment (Annex 3). Of the 2245 estimated ABOs, 935 (42\%) were stillbirths, 412 (18\%) neonatal deaths, 333 $(15 \%)$ premature birth and/or low-birthweight infants, and 565 (25\%) live-born infants with clinical symptoms.

CS cases born to women who did not attend ANC (Figure 2b, red bar segments) were estimated to have fallen dramatically by 2016, while numbers in women who attended ANC but were not screened also decreased (orange bar segments). Cases among mothers screened but not treated (yellow bar segments) were stable over time, indicating a programmatic bottleneck. Cases among mothers screened and treated (blue bar segments) rose slightly, reflecting increasing screening coverage. In 2016, of the 3851 estimated CS cases, 6\% were among mothers not in ANC, $27 \%$ in mothers attending ANC but not screened, $54 \%$ in mothers screened but not treated, and $13 \%$ in mothers treated.

ANC-based screening and treatment were estimated to have averted increasing numbers of CS, with 3472 cases avoided in 2008 and 5633 cases prevented in 2016 (Figure 2b, green bar segments).

\section{Completeness of congenital syphilis case reporting}

Reported CS cases fluctuated in Colombia, with a peak in 2011 (2 078 cases), followed by a decline to around 700 annual cases in 2015 and 2016, after a change in the national case definition (Annex 4). The 717 cases reported in 2016 represent $19 \%$ of Spectrum-estimated CS cases.

\section{Sensitivity analysis}

Table 2 shows the effect that varying assumptions have on the estimated prevalence of gonorrhea, chlamydia, and syphilis in adult women and on new cases of congenital syphilis and of syphilis-associated adverse birth outcomes in Colombia in 2016

For gonorrhea, the prevalence estimated for women in 2016 changed from $0.70 \%(0.15 \%-1.9 \%)$ to $0.50 \% \quad(0.09 \%$ $1.5 \%$ ) when adding to the estimation data from four good-quality studies from Colombia that were not eligible because

FIGURE 2. Estimated number of cases of congenital syphilis (CS) in Colombia, 2008-2016, by: (a) birth outcome, compared to the reported number of cases of CS, and (b) antenatal care (ANC) history and prevented adverse birth outcome

(a) Estimated number of cases of CS by birth outcome

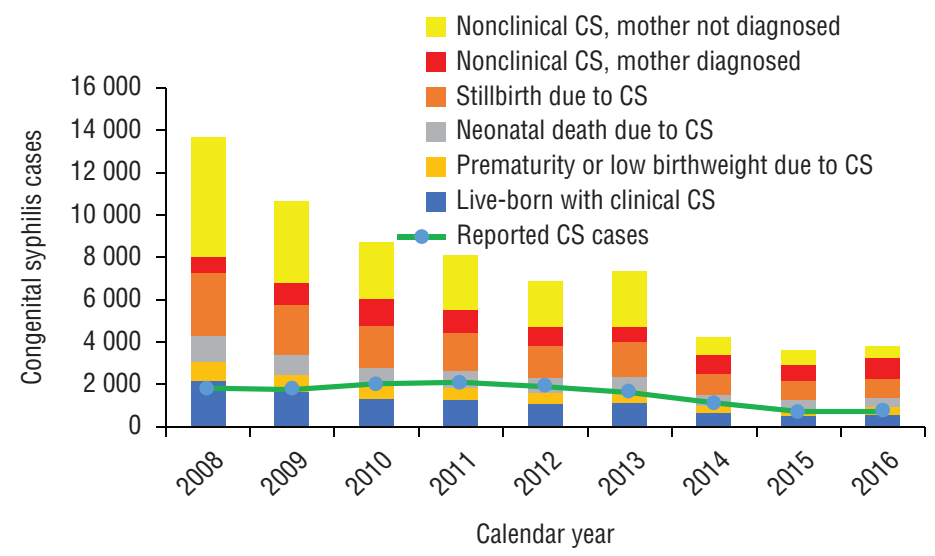

(b) Estimated number of cases of CS by ANC history and prevented adverse outcome (as a result of efforts to screen and treat pregnant women for syphilis)

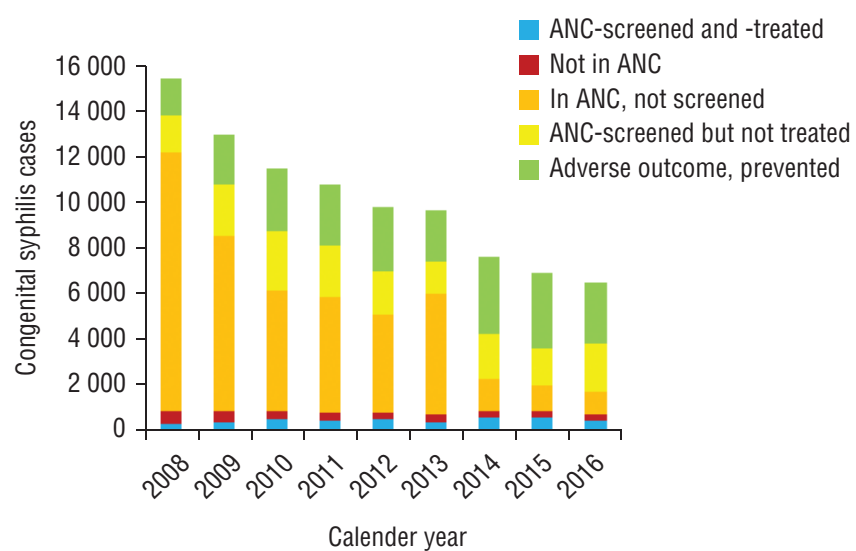

Source: Prepared by the authors from the study's estimations based on the data presented in the Annexes. 
of nonrepresentativeness (patients with symptoms, selected youth who were sexually active, Annex 1) (Table 2).

For chlamydia, adding seven highquality Colombian studies that were not eligible by default (for the same reasons as for excluded gonorrhea studies; Annex 1,) estimated prevalence for women in 2016 changed from 9.2\% $(4.4 \%-15.4 \%)$ to $8.8 \%(4.4 \%-14.7 \%)$.

For syphilis, one sensitivity analysis added national universal blood donor screening data into the estimation. The blood donor screening data provided a long time series (1993-2016). However, blood donors are typically a relatively lower-risk, healthier population and less representative of the overall adult population (see footnote to Annex 2). When adding donor data, the estimated prevalence in 2016 slightly decreased, from the default $1.25 \%$ to $1.04 \%$ (Table 2 ). Also, the historic time trend changed, from the default estimate of a decline (from 2.6\% in 1995 to $1.25 \%$ in 2016) into a trend of a slight increase (from $0.88 \%$ to $1.04 \%$ ).

\section{DISCUSSION}

The first-ever estimates of the burden of STIs in Colombia that we presented were based on national and subnational STI survey and surveillance data, using the Spectrum-STI tool. These estimates highlighted a persistently high burden of gonorrhea and chlamydia, a declining syphilis prevalence, and more congenital syphilis cases than are routinely reported. For gonorrhea and chlamydia, available prevalence data were from subnational small-scale surveys that give a picture of probable prevalence levels but do not allow a robust estimation of national historic trends.
Our estimates of gonorrhea and chlamydia in Colombia were similar to WHO estimates for the Andean region for 2012 (9). However, our estimated prevalence for chlamydia was 14-fold that of gonorrhea in 2016, a greater difference than in WHO's Andean and other regional estimates (9). A relatively strong predominance of chlamydia over gonorrhea in Colombia is supported by the high estimated share of chlamydia as a cause of urethral discharge, as reported in national and subnational etiological studies (23-25).

Reported gonorrhea case numbers in Colombia (Annex 4) were strikingly low compared to estimated incident cases, even when we consider that (globally) only $64 \%$ and $54 \%$ of male gonorrhea and chlamydia, respectively, and $34 \%$ and $17 \%$ of female gonorrhea and chlamydia infections, respectively, may be symptomatic (9). STI case reports are assembled from management information systems, and laboratory diagnoses are collected in a passive way, explaining the very low reporting completeness.

For adult syphilis, Spectrum-STI estimated more than double the prevalence and incidence in Colombia than did WHO's 2012 estimate for the Andean region. Based on multiple years of ANC survey and surveillance data, Spectrum-STI estimated adult and congenital syphilis rates to be falling, reflecting improving ANC-based syphilis screening and treatment efforts. Recent changes in Colombia's case definition for maternal syphilis limit the diagnosis to cases with both positive RPR and Treponema pallidum results. Our estimation suggested that only $19 \%$ of CS cases (per the WHO case definition) are reported in Colombia. Reported cases are likely mostly live-born infants with clinical symptoms-while syphilis-associated stillbirths and neonatal deaths may not be reported. Efforts to revise the national CS reporting definition to include syphilis-associated stillbirth and neonatal deaths are underway, following this estimation exercise.

Elimination of CS in Colombia will require increased surveillance and improved syphilis screening and treatment of pregnant women. Prioritized activities to reduce CS and improve CS case finding could include: (1) earlier syphilis ANC screening (over $80 \%$ of screening happens in the third trimester of pregnancy, even though women frequently enter ANC in the first or second trimester (26)); (2) prompt treatment of pregnant women with syphilis, as treatment late in the third trimester may not prevent CS; (3) improved follow-up of pregnant women with syphilis and their infants; and (4) adjustment of the CS case definition to include syphilis-associated stillbirths and neonatal deaths. In addition, activities to improve partner notification and treatment (from 50\% coverage among all ANC women diagnosed with syphilis over 2014-2016 (26)) and prevention and control of syphilis in key groups and in the general adult population are needed to support reducing syphilis rates among pregnant women.

These current estimations are limited by the quality and quantity of prevalence data, and by assumptions underlying the model or those made in the absence of data. Uncertain assumptions affected gonorrhea and chlamydia more so than syphilis. Lacking sufficient national prevalence data, the gonorrhea and chlamydia estimations additionally used

TABLE 2. Sensitivity analysis showing the effect of varying assumptions on the estimated prevalence (with $95 \%$ confidence intervals) of gonorrhea, chlamydia, and syphilis in adult women (15-49 years) and on new cases of congenital syphilis (CS) and of syphilis-associated adverse birth outcomes in Colombia in 2016

\begin{tabular}{|c|c|c|c|c|c|}
\hline Parameter altered & $\begin{array}{l}\text { Gonorrhea } \\
\text { prevalence, women }\end{array}$ & $\begin{array}{l}\text { Chlamydia } \\
\text { prevalence, women }\end{array}$ & $\begin{array}{l}\text { Syphilis } \\
\text { prevalence, women }\end{array}$ & $\begin{array}{l}\text { Congenital } \\
\text { syphilis cases }\end{array}$ & $\begin{array}{l}\text { Adverse birth } \\
\text { outcomes } \\
\text { (subset of CS) }\end{array}$ \\
\hline None (default estimate) & $\begin{array}{c}0.70 \% \\
(0.15 \% \text { to } 1.9 \%)\end{array}$ & $\begin{array}{c}9.2 \% \\
(4.4 \% \text { to } 15.4 \%)\end{array}$ & $\begin{array}{c}1.25 \% \\
(1.21 \% \text { to } 1.29 \%)\end{array}$ & 3851 & 2245 \\
\hline $\begin{array}{l}\text { Gonorrhea and chlamydia: add less-representative } \\
\text { prevalence studies from Colombia into the estimation } \\
\text { (see Annex 1; each of these assigned a weight of } 20 \% \text { ) }\end{array}$ & $\begin{array}{c}0.50 \% \\
(0.09 \% \text { to } 1.5 \%)\end{array}$ & $\begin{array}{c}8.8 \% \\
(4.4 \% \text { to } 14.7 \%)\end{array}$ & $\begin{array}{l}\text { Not applicable/as } \\
\text { default }\end{array}$ & $\begin{array}{l}\text { Not applicable/as } \\
\text { default }\end{array}$ & $\begin{array}{l}\text { Not applicable/as } \\
\text { default }\end{array}$ \\
\hline $\begin{array}{l}\text { Syphilis: add blood donor screening data (using weights } \\
\text { as shown in Annex 2) }\end{array}$ & $\begin{array}{l}\text { Not applicable/as } \\
\text { default }\end{array}$ & $\begin{array}{l}\text { Not applicable/as } \\
\text { default }\end{array}$ & $\begin{array}{c}1.04 \% \\
(0.96 \% \text { to } 1.19 \%)\end{array}$ & 3204 & 1868 \\
\hline
\end{tabular}

Source: Prepared by the authors from the study's estimations, based on the data presented in the annexes. 
prevalence data from national and subnational studies from Brazil and Peru, but it is uncertain if these data are representative for Colombia. Incidence estimates were more uncertain than prevalence, given assumptions on episode durations and access to treatment, which were taken from global meta-analysis that was not validated on Colombia data. Results for men were based on female estimates, applying global fixed male-tofemale prevalence ratios. For syphilis, we assumed a 1:1 male-to-female ratio. However, national blood donor screening data found ratios of 1.2 to 1.5 over 2010-2016, so we may have underestimated male rates. For gonorrhea and chlamydia, there were no national data to validate the assumed sex ratios.

Our estimations were not informed by prevalence data from high-risk groups. Few such data are available in Colombia. Among female sex workers (FSWs), a study in the city of Montería in 2004 found a prevalence for gonorrhea of $4.3 \%$ and for chlamydia of $15.9 \%$ (27); a study in Bogotá done in 2001-2002 found a syphilis prevalence of $10.3 \%$ (28). Applying these prevalences to the number of FSWs for the entire country-projected in the context of Colombia's national HIV estimations (29)—suggests that FSWs account for a prevalence of $6 \%, 11 \%$, and $12-13 \%$, respectively, of chlamydia, gonorrhea, and active syphilis among women. These values are in line with the $10 \%$ share assumed in Spectrum (3) and in past regional STI estimations (9). No data were available from men having sex with men or other male risk groups, and Spectrum's assumption that higher-risk men add 10\% to the national male STI burden remains to be examined.

Critical data to inform the STI burden and trends are regular population-based prevalence measurements for multiple STIs, in low-risk men and women in urban and rural areas. Securing funding for nationwide surveys is challenging, but opportunities may be exploited for tagging STI screening onto existing health and surveillance activities. For example, screening of pregnant women for gonorrhea and chlamydia would bring both immediate clinical benefits and useful STI surveillance data; routine blood donor screening might be expanded to periodically include gonorrhea and chlamydia (with urine samples); and screening and treatment programs for chlamydia in adolescents is recommended in the WHO global STI strategy for 2016-2021 (30). Our estimates of high gonorrhea and chlamydia case numbers suggest that training and capacity building among health professionals could improve diagnosis and reporting. Interpretation of case reports would be helped by monitoring of annual numbers of STI tests conducted (since more tests will generate more diagnosed cases), and by studies to understand patterns in access to STI care, treatment-seeking behaviors, and barriers.

\section{REFERENCES}

1. Ministerio de Salud y Protección Social; Programa Conjunto de las Naciones Unidas sobre el VIH/Sida, Grupo Temático para Colombia. Plan Nacional de Respuesta ante las ITS-VIH/Sida 20142017. Bogotá; ONUSIDA: 2014.

2. Pan American Health Organization. Elimination of mother-to-child transmission of HIV and syphilis in the Americas. Update 2016. Washington, D.C.: PAHO; 2017.

3. Korenromp EL, Mahiané G, Rowley J, Nagelkerke N, Abu-Raddad L, Ndowa F, et al. Estimating prevalence trends in adult gonorrhoea and syphilis prevalence in low- and middle-income countries with the Spectrum-STI model: results for Zimbabwe and Morocco from 1995 to 2016. Sex Transm Infect. 2017 Dec;93(8):599-606.

4. El Kettani A, Mahiané G, Abu-Raddad L, Smolak A, Rowley J, Nagelkerke N, et al. Trends in adult chlamydia and gonorrhea prevalence, incidence and urethral discharge case reporting in Morocco over 1995 to 2015 - estimates using the SpectrumSexually Transmitted Infection model. Sex Transm Dis. 2017 Sept.;44(9):557-64.

5. Bennani A, El Rhilani H, El Kettani A, Alami K, Hançali A, Youbi M, et al. The prevalence and incidence of active syphilis in Morocco, 1995-2016: model-based estimation and implications for STI surveillance. PLoS One. 201724 August; 12(8):e0181498.

6. Badrakh J, Zayasaikhan S, Davaalkham J, Erdenetungalag E, Jadambaa N, Munkhbaatar S, et al. Trends in adult chlamydia and gonorrhea prevalence, incidence and urethral discharge case reporting in Mongolia over 1995-2016 estimates using the Spectrum-STI model. Western Pac Surveill Response J. 2017 Dec 1;8(4):20-9.

7. Enkhbat E, Korenromp EL, Badrakh J, Zayasaikhan S, Baya P, Orgiokhuu E,
In conclusion, STI surveillance and monitoring data entered into the Spectrum-STI tool demonstrated a persistently high burden of STIs in Colombia, while falling congenital syphilis rates reflect improved ANC-based screening. Strengthened surveillance and future refined Spectrum estimations should support actions to prevent and control STIs and eliminate congenital syphilis in the country.

Acknowledgments. We thank Dr. Guy Mahiané (Avenir Health) for the statistical design of the Spectrum-STI estimation method and for the statistical analysis in the Results section of the article. We are also grateful to Kendall Hecht (Avenir Health) for programming the Spectrum-STI online user interface.

Funding. The project was funded by the World Health Organization, Department of Reproductive Health and Research, STI program.

\section{Conflicts of interest. None declared.}

Disclaimer. Authors hold sole responsibility for the views expressed in the manuscript, which may not necessarily reflect the opinion or policy of the RPSP/ $P A J P H$, the Pan America Health Organization, the World Health Organization, or the U.S. Centers for Disease Control and Prevention. et al. Adult female syphilis prevalence, congenital syphilis case incidence and adverse birth outcomes, Mongolia 20002016: estimates using the Spectrum STI tool. Infect Dis Model. 2018;3:13-22, https: / / doi.org/10.1016/j.idm.2018 .03 .003 .

8. Taylor M, Alonso MA, Korenromp EL, Broutet N. World Health Organization global health sector strategy on sexually transmitted infections: an evidence-toaction summary for Colombia. Rev Colomb Obstet Ginecol. 2017;68(3):193-201.

9. Newman L, Rowley J, VanderHoorn S, Wijesooriya NS, Unemo M, Stevens G, et al. Global estimates of the prevalence and incidence of four curable sexually transmitted infections in 2012 based on systematic review and global reporting. PLoS One. 2015;10(12):e0143304.

10. Chico RM, Mayaud P, Ariti C, Mabey D, Ronsmans C, Chandramohan D. Prevalence of malaria and sexually transmitted and 
reproductive tract infections in pregnancy in sub-Saharan Africa: a systematic review. JAMA. 2012 May 16;307(19): 2079-86.

11. Orroth KK, Korenromp EL, White RG, Changalucha J, de Vlas SJ, Gray RH, et al. Comparison of STD prevalences in the Mwanza, Rakai, and Masaka trial populations: the role of selection bias and diagnostic errors. Sex Transm Infect. 2003 Apr;79(2):98-105.

12. United Nations, Department of Economic and Social Affairs, Population Division. World Population Prospects: the 2015 revision [database]. Available from: http:// esa.un.org/unpd/wpp/ Accessed on 11 May 2017.

13. Gallant AR, Fuller WA. Fitting segmented polynomial regression models whose join points have to be estimated. J Am Stat Assoc. 1973 March;68(341):144-7.

14. Park SH. Experimental designs for fitting segmented polynomial regression models. Technometrics. 1978 May;20(2):151-4.

15. Smolak A, Rowley J, Nagelkerke N, Kassebaum N, Chico RM,Korenromp EL, et al. Trends and predictors of syphilis prevalence in the general population: global pooled analyses of 1103 prevalence measures including 136 million syphilis tests. Clin Infect Dis. 2018 Apr 3;66(8):1184-91.

16. Ministro de Salud y Protección Social; Asociación Probienestar de la Familia Colombiana. Encuesta Nacional de Demografía y Salud. Bogotá: MinSalud; 2017.

17. World Health Organization. Guidance for use of WHO tool to estimate syphilis in pregnancy and associated adverse outcomes. Available from: http://www.who. int/reproductivehealth / topics / rtis / Guidance.pdf Accessed on 9 May 2018.

18. Wijesooriya NS, Rochat RW, Kamb ML, Turlapati P, Temmerman M, Broutet N, et al. Global burden of maternal and congenital syphilis in 2008 and 2012: a health systems modelling study. Lancet Glob Health. 2016;4(8):e525-33.

19. Ojeda G, Ordóñez M, Ochoa LH. Encuesta Nacional de Demografía y Salud 2010. Bogotá: Asociación Probienestar de la Familia Colombiana; 2011.

20. World Health Organization. Global guidance on criteria and processes for validation: elimination of mother-to-child transmission (EMTCT) of HIV and syphilis. Geneva: WHO; 2014.

21. Gomez GB, Kamb ML, Newman LM, Mark J, Broutet N, Hawkes SJ. Untreated maternal syphilis and adverse outcomes of pregnancy: a systematic review and meta-analysis. Bull World Health Organ. 2013 Mar 01;91(3):217-26.

22. Blencowe H, Cousens S, Kamb M, Berman S, Lawn JE. Lives Saved Tool supplement detection and treatment of syphilis in pregnancy to reduce syphilis related stillbirths and neonatal mortality. BMC Public Health. 2011 Apr 13;11 Suppl 3:S9.

23. Ángel-Müller E, González MP, Núñez L, Pacheco J, Tolosa JE, Díaz LA, et al. [A pilot study of the frequency of genital tract infection in symptomatic women and the use of rapid diagnostic tests in two groups of women from Bogotá, Colombia, 2008]. Rev Colomb Obstet Ginecol. 2010;61(3):220-30.

24. Ángel-Müller E, Rodríguez A, NúñezForero LM, Moyano LF, González P, Osorio E, et al. The prevalence of and factors associated with $\mathrm{C}$. trachomatis, $\mathrm{N}$. gonorrheae, T. vaginalis, C. albicans infection, syphilis, HIV and bacterial vaginosis in females suffering lower genital tract infection symptoms in three healthcare attention sites in Bogotá, Colombia, 2010. Rev Colomb Obstet Ginecol. 2012; 63:25-35.

25. Acosta J, Prieto F, Rodriguez D, Rueda C. [The status of sexually transmitted diseases, Colombia, 1976-2000]. Biomedica. 2002 Mar;22(1):77-88.

26. Colombia, Instituto Nacional de Salud. Informes de evento de sífilis gestacional y congénita 2005-2016. Bogotá: Instituto Nacional de Salud; 2017.

27. Alvis N, Mattar S, Garcia J, Conde E, Diaz A. [Sexually-transmitted infection in a high-risk group from Montería, Colombia]. Rev Salud Publica (Bogota). 2007 Jan-Mar;9(1):86-96.

28. Mejia A, Bautista CT, Leal L, Ayala C, Prieto F, de la Hoz F, et al. Syphilis infection among female sex workers in Colombia. J Immigr Minor Health. 2009 Apr;11(2):92-8.

29. Luque R, Cuellar D. Prevalencia estimada de VIH/SIDA entre la población de 15 y 49 años. Bogotá: Ministerio de Salud y Protección Social; 2016.

30. World Health Organization. Global health sector strategy on sexually transmitted infections 2016-2021. Towards ending STIs. Geneva: WHO; 2016.

Manuscript received on 7 December 2017. Revised version accepted for publication on 6 March 2018. 
RESUMEN

Estimaciones sobre la prevalencia y la incidencia de sífilis, clamidiasis, gonorrea y sífilis congénita en Colombia, 1995-2016

Palabras clave
Objetivos. Estimar la prevalencia e incidencia en los adultos (de 15 a 49 años de edad) de sífilis activa, gonorrea y clamidiasis, así como la incidencia de sífilis congénita y resultados adversos del embarazo en Colombia durante el período de 1995 al 2016.

Métodos. Usando las herramientas del modelo epidemiológico Spectrum-STI se estimó la prevalencia de gonorrea y clamidiasis como promedios móviles entre las distintas prevalencias observadas en encuestas representativas de la población general. En cuanto a la sífilis en los adultos, Spectrum-STI aplicó la regresión polinomial segmentada a los datos sobre prevalencia recopilados en encuestas de atención prenatal, el tamizaje sistemático en la atención prenatal y encuestas a la población general. Los casos de sífilis congénita y de resultados adversos del embarazo se estimaron a partir de las cifras de Spectrum sobre sífilis materna y proporciones de mujeres examinadas y tratadas por sífilis, aplicando las definiciones de casos y probabilidades de riesgo de la Organización Mundial de la Salud.

Resultados. El modelo Spectrum estimó que en el 2016 la prevalencia de la gonorrea fue de $0,70 \%$ (intervalo de confianza de 95\% [IC]: 0,15\%-1,9\%) en las mujeres y de $0,60 \%(0,1 \%-1,9 \%)$ en los hombres, y que la prevalencia de la clamidiasis fue de $9,2 \%$ $(4,4 \%-15,4 \%)$ en las mujeres y de $7,4 \%(3,5 \%-14,7 \%)$ en los hombres, sin datos científicos acerca de las tendencias durante el período 1995-2016. La prevalencia de la sífilis activa en el 2016 fue de $1,25 \%(1,22-1,29 \%)$ en las mujeres y de 1,25\% (1,1\%-1,4\%) en los hombres, con una reducción de 2,6\% (2,1\%-3,2\%) en las mujeres con respecto a 1995. Los casos correspondientes de sífilis congénita en el 2016 (incluidos los asintomáticos) sumaron en total 3 851, de los cuales 2245 fueron resultados adversos del embarazo. Las cifras anuales estimadas de sífilis congénita y resultados adversos del embarazo disminuyeron entre el 2008 y el 2016, lo que reflejó un descenso en la prevalencia materna y un aumento de casos evitados mediante el tamizaje y el tratamiento durante la atención prenatal.

Conclusiones. Los datos disponibles sobre vigilancia y seguimiento sintetizados en Spectrum-STI, así como los consiguientes estimados nacionales de infecciones de transmisión sexual (ITS) hechos por primera vez en Colombia, pusieron de relieve la carga de morbilidad por ITS persistentemente alta en ese país. Se estima que la sífilis en los adultos y la sífilis congénita van en descenso, lo que refleja mejoras en las actividades de tamizaje. Un fortalecimiento de la vigilancia, incluso con tamizaje periódico en las poblaciones de bajo riesgo, y estimaciones más refinadas con Spectrum en el futuro deberían brindar apoyo a la planificación y la ejecución de medidas para la prevención y el control de las infecciones de transmisión sexual, incluida la eliminación de la sífilis congénita.

Enfermedades de transmisión sexual; sífilis; gonorrea; chlamydia; vigilancia; Colombia. 
RESUMO

\section{Estimativas da incidência e prevalência de sífilis, clamídia, gonorreia e sífilis congênita na Colômbia, 1995-2016}

Palavras-chave
Objetivos. Estimar a incidência e a prevalência na população adulta (com idade de 15-49 anos) de sífilis ativa, gonorreia e clamídia e a incidência de sífilis congênita (SC) e desfechos adversos congênitos na Colômbia no período de 1995 a 2016.

Métodos. O modelo epidemiológico Spectrum-STI foi o instrumento usado para estimar a prevalência de gonorreia e clamídia como médias móveis nas prevalências observadas em pesquisas representativas da população geral. A sífilis em adultos foi estimada com a regressão polinomial segmentada aplicada ao modelo Spectrum-STI com dados de prevalência obtidos de pesquisas da atenção pré-natal, exames pré-natais de rotina de detecção precoce e pesquisas da população geral. Casos de SC e desfechos adversos congênitos foram estimados a partir das estimativas de sífilis materna do modelo Spectrum e percentuais de mulheres que fizeram testes de detecção e foram tratadas para sífilis, segundo as definições de casos da Organização Mundial da Saúde (OMS) e probabilidades de risco.

Resultados. O modelo Spectrum estimou, para 2016, uma prevalência de gonorreia de $0,70 \%$ (intervalo de confiança de $95 \%$ [IC 95\%] 0,15\%-1,9\%) no sexo feminino e 0,60\% (0,1\%-1,9\%) no sexo masculino e uma prevalência de clamídia de $9,2 \%(4,4 \%-$ $15,4 \%)$ no sexo feminino e $7,4 \%(3,5 \%-14.7 \%)$ no sexo masculino, sem evidência de tendências no período 1995-2016. A prevalência de sífilis ativa em 2016 foi de 1,25\% $(1,22-1,29 \%)$ no sexo feminino e $1,25 \%(1,1 \%-1,4 \%)$ no sexo masculino, demonstrando um declínio da prevalência de 2,6\% (2,1\%-3,2\%) observada em 1995 para o sexo feminino. Houve, ao todo, 3.851 casos correspondentes de SC em 2016 (incluindo casos assintomáticos), dos quais 2.245 foram desfechos adversos congênitos. Observou-se uma redução nas estimativas anuais de SC e desfechos adversos congênitos em 20082016, refletindo a diminuição da prevalência materna e o número crescente de casos evitados com exames pré-natais de detecção e tratamento.

Conclusões. Os dados disponíveis de vigilância e monitoramento condensados no modelo Spectrum-STI, e as resultantes estimativas nacionais de infeções sexualmente transmissíveis (IST) obtidas pela primeira vez na Colômbia, evidenciam a alta carga persistente de IST no país. Estima-se que a ocorrência de sífilis do adulto e sífilis congênita esteja diminuindo em decorrência da melhoria nos esforços de detecção precoce. A vigilância reforçada, consistindo também de exames periódicos de detecção precoce nas populações de baixo risco e estimavas futuras aprimoradas do instrumento Spectrum, deve sustentar o planejamento e a implementação de controle e prevenção de IST e a eliminação da SC.

Doenças sexualmente transmissíveis; sífilis; gonorreia; chlamydia; vigilância; Colômbia. 